\title{
Potassium applied under drought improves physiological and nutrient uptake performances of wheat (Triticum Aestivun L.)
}

\author{
M. A. Samar Raza ${ }^{1 *}$, M.Farrukh Saleem², G. Mustafa Shah ${ }^{3}$, M. Jamil ${ }^{1}$ and I. Haider Khan ${ }^{4}$ \\ ${ }^{1}$ University College of Agriculture \& Environmental Sciences, The Islamia University of Bahawalpur, Pakistan ; ${ }^{2}$ Department \\ of Agronomy, University of Agriculture, Faisalabad, Pakistan; ${ }^{3}$ Organic Farming Systems group, Wageningen University, The \\ Netherlands; ${ }^{4}$ College of Agriculture Dera Ghazi Khan, Pakistan; *Email: aownsamar@gmail.com; Phone: +923336697595; \\ Fax: +920629250232
}

\begin{abstract}
The physiological and nutrient uptake performance of two wheat (Triticum aestivum L.) cultivars (Lasani-2008 and Auqab-2000) to foliar application of $1 \%$ potassium (K) at three different growth stages (tillering, flower initiation and grain filling) was investigated under water limited environment in a wire house experiment at the Nuclear Institute for Agriculture and Biology, Faisalabad. The aim was to find out the best $\mathrm{K}$ application stage for improvement in drought tolerance potential. Drought stress was created by withholding irrigation at the three growth stages and then K was sprayed with carboxymethyl cellulose as a sticking agent, whereas Tween-20 was used as a surfactant for foliar spray. At maturity, aboveground nitrogen, phosphorus, K, sodium and calcium uptakes by the crop were measured. Besides, water potential, osmotic potential and turgor potential of crop were also estimated. The results indicated that the drought stress at all three critical growth stages of wheat adversely affected plant's nutrient uptake, water potential, osmotic potential and turgor potential of wheat plants. The exogenous application of $\mathrm{K}$ under drought stress at all three critical growth stages enhanced tolerance of wheat by reducing toxic nutrient's uptake and improving the physiological efficiency. In this regards, both varieties showed uniform behavior. Maximum improvement in all the recorded nutrients uptake and physiological parameters was achieved when $\mathrm{K}$ was applied at grain filling stage of both cultivars.
\end{abstract}

Keywords: drought, foliar application, potassium, wheat, tolerance, physiological efficiency

\section{Introduction}

Drought is the most devastating abiotic stress factor, affecting growth and yield of various crops. Among the other environmental stresses, it is by far adversely reducing the crop productivity (Pennisi 2008; Farooq et al., 2008); however, different mechanisms have been reported to cope with drought. It is now well evident that drought stressed plants exhibit various physiological, biochemical and molecular adaptations to thrive under drought stress (Arora et al., 2002). Water stress prevails longer in arid and semi-arid environments besides other factors which causes the reduction in crop growth and yield (Ashraf et al., 1995). 
It has now become the established fact that drought stress reduces crop yield in wheat regardless of the growth stage at which it occurs. Reduction in productivity and impaired crop growth are caused when plants suffer from drought stress (Farooq et al., 2008).

Concept about the drought tolerance is one of the most ambiguous in literature (Blum 2005). Many tolerance mechanisms have been evolved, some of which are; dehydration tolerance level using genetic engineering techniques under laboratory condition (Jenks et al. ,2007; Nelson et al., 2007), reactive oxygen species detoxification under stress condition (Lee et al. 2007; Yang et al., 2007; Zhu et al., 2007) and facilitating the drought avoidance mechanism with hormonal balance (Rivero et al. 2007).

Besides various adaptive mechanisms; potassium (K) sprayed under drought condition can improve the tolerance of crop plants to various types of abiotic stresses, and it also improved subsequent growth and yield. Mengel and Kirkby (2001) reported that K improves physiological processes by the regulation of turgor pressure and photosynthesis; translocation of cations and enzymes activation, while, Cakmak (2005) also observed that plant suffering from drought stress required more internal $\mathrm{K}$. In legumes, devastating effects of drought can be alleviated by rich K supply (Sangakkara et al.. 2000). Yield limiting effect of water deficit could be overcome by increasing $\mathrm{K}$ supply (Damon and Rengel 2007). The bottom lines of the reviewed results in this section indicate that under drought stress conditions, yield losses can be minimized by the sufficient supply of K. However, its application effect at various plant growth stages is not well understood yet.

The objective of present work was to study the possible role of $\mathrm{K}$ applied on wheat foliage at different growth stages under drought, in mitigation of stress in terms of physiological components and nutrients uptake.

\section{Materials and Methods}

\subsection{Experiment description}

To pursue the objective outlined above, an experiment was carried out for 138 days in pots at Nuclear Institute for Agriculture and Biology, Faisalabad, Pakistan (latitude $=31^{\circ} \mathrm{N}$, longitude $=73^{\circ} \mathrm{E}$, and an altitude of 184.4 meters above the sea level). The experiment was conducted in a wire house in order to avoid any (i) insect/birds attack on the plants and (ii) interruption by rainfall. The latter was done by covering the wire house structure with polyethylene plastic sheet at the time of rainfall. Physico-chemical analysis of the experimental soil showed that it contained; sand $22 \%$, silt $13 \%$, clay $65 \%$, organic matter $0.83 \%$, total nitrogen (N) $0.33 \mathrm{mg} \mathrm{kg}^{-1}$ dry soil, phosphorous (P) 4.9 $\mathrm{mg} \mathrm{kg}^{-1}$ dry soil, $\mathrm{K} 128 \mathrm{mg} \mathrm{kg}^{-1}$ dry soil, and calcium (Ca) $101 \mathrm{mg} \mathrm{kg}^{-1}$ dry soil. The $\mathrm{pH}$ of the soil was 7.7 .

The soil was filled in pots with amount of $7 \mathrm{~kg}$ dry soil per pot and subsequently the recommended doses of $\mathrm{N}$ and $\mathrm{P}\left(120 \mathrm{~g} \mathrm{pot}^{-1}\right)$ was applied. Thereafter, two commonly grown wheat cultivars (Lasani-2008 and Auqab-2000) in Pakistan were sown at a rate of 10 seeds per pot. After 14 days of germination, plants were thinned to four plants per pot. During the growth period, drought stress was created by withholding irrigation at different growth stages. Thereafter $\mathrm{K}$ at $1 \%$ was sprayed with carboxymethyl cellulose $(5 \%$ solution) as a sticking agent, whereas Tween-20 (0.1\% solution) was used as a surfactant for foliar spray. In pots of control treatment $\left(\mathrm{K}_{0}\right) 300 \mathrm{ml}$ of water was applied, whereas this amount was only $100 \mathrm{ml}$ water in all the other pots with drought treatments. In order to compare $\mathrm{K}$ vs. no $\mathrm{K}$ treatments, the plants that were not treated with $\mathrm{K}$ were sprayed with the same amount of the carboxymethyl cellulose and Tween-20. K was applied to both cultivars through foliar spray on drought created pots at three critical growth stages; Zadoks GS 22, GS 60 and GS 73, representing tillering, flower initiation and grain filling stages, respectively. The $\mathrm{K}$ application/drought induction scheduled viz., $\mathrm{K}_{0}$ (no drought and no $\mathrm{K}$ spray), $\mathrm{K}_{1}$ (drought at tillering stage 
without $\mathrm{K}$ spray), $\mathrm{K}_{2}$ (drought at tillering stage with $\mathrm{K}$ spray), $\mathrm{K}_{3}$ (drought at flower initiation stage without $\mathrm{K}$ spray), $\mathrm{K}_{4}$ (drought at flower initiation stage with $\mathrm{K}$ spray), $\mathrm{K}_{5}$ (drought at grain filling stage without $\mathrm{K}$ spray) and $\mathrm{K}_{6}$ (drought at grain filling stage with $\mathrm{K}$ spray). All the treatments were arranged in completely randomized design with three replicates. Under controlled condition $\mathrm{K}_{0}$ (no drought and no K spray) plants were given.

\subsection{Physiological attributes}

At each growth stages, a fully expanded youngest leaf of two plants of each treatment was used to determine the leaf water potential. The measurements were made from 8.00 to 10.00 A.M. with Scholander type Pressure Chamber. The selected leaves used to determine water potential, was put in a freezer below $-20^{\circ} \mathrm{C}$ for seven days. The frozen leaf material was then thawed and cell sap extracted with the help of a disposable syringe. The sap so extracted was directly used for the determination of osmotic potential using an osmometer (Wescor 5500). The turgor potential $(\Psi \mathrm{p})$ is the difference between osmotic potential $\left(\Psi_{\mathrm{s}}\right)$ and water potential $\left(\Psi_{\mathrm{w}}\right)$ values. So it was calculated as $\left(\Psi_{\mathrm{p}}\right)=\left(\Psi_{\mathrm{w}}\right)-\left(\Psi_{\mathrm{s}}\right)$.

\subsection{Nutrients uptake}

At maturity, the plant's shoot material with leaves was oven-dried at $70^{\circ} \mathrm{C}$ till constant weight and ground in a Wiley Micro Mill to pass through a $2 \mathrm{~mm}$ sieve. The dried ground material $(0.5 \mathrm{~g})$ was digested in sulphuric acid and hydrogen peroxide (Wolf 1982). The digested samples were run on flame photometer to determine the sodium ( $\mathrm{Na}$ ), $\mathrm{K}$ and $\mathrm{Ca}$. A graded series of standards (ranging from 10-100 ppm) of these ions were prepared and standard curves were drawn. The concentrations of $\mathrm{Na}, \mathrm{K}$ and $\mathrm{Ca}$ in plant samples from flame photometer were computed through standard curves of each, separately. The total $\mathrm{N}$ content was estimated by micro-Kjeldhal's method (Bremner 1965). The total $\mathrm{P}$ content was analyzed by spectrophotometer. Effects of the treatments on nutrient uptake were statistically analysed using Fisher's analysis of variance technique in Statistix (8th edition, Analytical Software, USA).
Differences among treatments means were compared by least significant different test at $5 \%$ probability level.

\section{Resuls}

The contrasts (drought vs. no drought) made it clear that drought significantly affected all physiological parameters and nutrients uptake by wheat (Table 1) and $\mathrm{K}$ application under drought improved most of these parameters. The collected data regarding water potential, osmotic potential and turgor potential (Figures 1, 2 and 3) and N, P, K, Ca and $\mathrm{Na}$ uptake (Table 1) indicated that both the varieties Lasani-2008 and Auqab-2000 showed uniform behavior to the $\mathrm{K}$ application. The foliar application of $\mathrm{K}$ on wheat varieties improved the drought tolerance in the plants.

Results on leaf water potential and osmotic potential of wheat (Figures 1 and 2) indicated that minimum (more negative) leaf water potential and osmotic potential was recorded from plants which were imposed drought than the control at all growth stages. Leaf water potential and osmotic potential was recorded maximum (less negative) under well-watered conditions $\left(\mathrm{K}_{0}\right)$. Foliar applications of $\mathrm{K}$ affected leaf water potential and osmotic potential and lowered negative effect of these parameters (Figures 1 and 2). Varietal differences, however, were non-significant. There was significant effect of drought and $\mathrm{K}$ sprays on leaf turgor potential (Figure 3). Under normal water supply $\left(\mathrm{K}_{0}\right)$, more leaf turgor potential was recorded. In contrast, less turgor potential was resulted when crop faced water stress, especially at flower initiation and grain filling stages. The exogenous applications of $\mathrm{K}$ under drought increased leaf turgor potential at all stages of crop growth. The varieties showed nonsignificant differences in turgor potential.

Among drought treatments, maximum improvement in all the recorded growth, yield and physiological parameters was achieved when $\mathrm{K}$ was applied at grain filling stage (K6) than other critical stages (Table 1). 
Table 1. Effect of drought and potassium spray on nutrient uptake in wheat. The values given in this table represent the mean of two varieties since there were no difference between them.

\begin{tabular}{|c|c|c|c|c|c|}
\hline \multirow[t]{2}{*}{ Treatments } & $\begin{array}{l}\text { Nitrogen } \\
\text { uptake }\end{array}$ & $\begin{array}{c}\text { Phosphorous } \\
\text { uptake }\end{array}$ & $\begin{array}{l}\text { Potassium } \\
\text { uptake }\end{array}$ & $\begin{array}{l}\text { Calcium } \\
\text { uptake }\end{array}$ & $\begin{array}{l}\text { Sodium } \\
\text { uptake }\end{array}$ \\
\hline & \multicolumn{5}{|c|}{$\left(\mathrm{mg} \mathrm{g}^{-1}\right)$} \\
\hline $\begin{array}{l}\mathbf{K}_{\mathbf{0}}=\text { Control (No drought } \\
\text { and no } \mathrm{K} \text { spray) }\end{array}$ & $0.029 \mathrm{c}$ & $1.81 \mathrm{a}$ & $5.33 \mathrm{~d}$ & $2.96 \mathrm{a}$ & $7.28 \mathrm{~d}$ \\
\hline $\begin{array}{l}\mathbf{K}_{\mathbf{1}}=\text { Drought at tillering } \\
\text { without K spray }\end{array}$ & $0.034 \mathrm{c}$ & $0.79 \mathrm{~cd}$ & $5.78 \mathrm{~cd}$ & $1.96 \mathrm{c}$ & $9.81 \mathrm{~b}$ \\
\hline $\begin{array}{l}\mathbf{K}_{\mathbf{2}}=\text { Drought at tillering } \\
\text { with } \mathrm{K} \text { spray }\end{array}$ & $0.036 \mathrm{~b}$ & $0.96 \mathrm{bc}$ & $6.64 \mathrm{bc}$ & $2.36 \mathrm{~b}$ & $8.02 \mathrm{c}$ \\
\hline $\begin{array}{l}\mathbf{K}_{\mathbf{3}}=\text { Drought at flower } \\
\text { initiation without } \mathrm{K} \text { spray }\end{array}$ & $0.037 \mathrm{ab}$ & $0.69 \mathrm{~d}$ & $6.03 \mathrm{~cd}$ & $2.84 \mathrm{a}$ & $10.61 \mathrm{a}$ \\
\hline $\begin{array}{l}\mathbf{K}_{\mathbf{4}}=\text { Drought at flower } \\
\text { initiation with } \mathrm{K} \text { spray }\end{array}$ & $0.039 \mathrm{a}$ & $0.80 \mathrm{~cd}$ & $7.49 \mathrm{ab}$ & $2.92 \mathrm{a}$ & $9.91 \mathrm{~b}$ \\
\hline $\begin{array}{l}\mathbf{K}_{\mathbf{5}}=\text { Drought at grain } \\
\text { filling stage without } \mathrm{K} \\
\text { spray }\end{array}$ & $0.035 \mathrm{bc}$ & $0.72 \mathrm{~d}$ & $6.19 \mathrm{~cd}$ & $2.06 \mathrm{c}$ & $10.34 \mathrm{ab}$ \\
\hline $\begin{array}{l}\mathbf{K}_{\mathbf{6}}=\text { Drought at grain } \\
\text { filling stage with } \mathrm{K} \text { spray }\end{array}$ & $0.039 \mathrm{a}$ & $1.12 \mathrm{~b}$ & $8.17 \mathrm{a}$ & $2.50 \mathrm{~b}$ & $7.95 \mathrm{c}$ \\
\hline Overall statistical analysis & & & & & \\
\hline Drought vs. no drought & $*$ & * & $*$ & $*$ & $*$ \\
\hline K vs. no K & NS & NS & NS & * & $*$ \\
\hline $\begin{array}{l}\text { Lasani-2008 vs. Auqab } \\
2000\end{array}$ & NS & NS & $*$ & $*$ & NS \\
\hline
\end{tabular}

Means within a column not sharing the same letters are significantly different with each other at 5\% probability.

* = Signifiant, NS = Non-significant 
Although crop gained maximum value for all the parameters in control treatment (no drought), however it was at par with the treatment where crop faced drought at grain filling stage but $\mathrm{K}$ was applied. Nutrient uptake is major factor contributing to the final yield of the crop. Well watered plants $\left(\mathrm{K}_{0}\right)$ showed the highest $\mathrm{P}$ and $\mathrm{Ca}$ uptake while $\mathrm{N}, \mathrm{K}$ and $\mathrm{Na}$ uptake were the lowest in this case (Table 1). Drought created at most of these stage $\left(\mathrm{K}_{1}, \mathrm{~K}_{3}\right.$ and $\left.\mathrm{K}_{5}\right)$ significantly reduced $\mathrm{P}$ and $\mathrm{Ca}$ uptake; whilst increased the $\mathrm{N}, \mathrm{K}$ and $\mathrm{Na}$ concentrations.

However, comparison of $\mathrm{K}_{1}$ vs. $\mathrm{K}_{2}, \mathrm{~K}_{3}$ vs. $\mathrm{K}_{4}$ and $\mathrm{K}_{5}$ vs. $\mathrm{K}_{6}$ revealed that application of $\mathrm{K}$ at any critical crop growth stage significantly increased wheat $\mathrm{N}, \mathrm{P}$, $\mathrm{K}$ and $\mathrm{Ca}$ uptakes and reduced $\mathrm{Na}$ uptake. Comparing the efficiency of $\mathrm{K}$ spray at different growth stages $\left(\mathrm{K}_{2}\right.$ vs. $\mathrm{K}_{4}$ vs. $\left.\mathrm{K}_{6}\right)$ indicated that nutrient uptake was affected maximum when $\mathrm{K}$ was applied under water stress at grain filling stage $\left(\mathrm{K}_{6}\right)$.

\section{Discussion}

Drought stress affected the crop growth and development significantly by affecting the physiological and biochemical parameters causing decrease in the final yield of wheat. Foliar application of $\mathrm{K}$ to wheat under water deficit condition on either growth stage (tillering, flower initiation and grain filling) significantly affected nutrients uptake and also affected water potential, osmotic potential and turgor potential of both wheat cultivars.

Drought stress at tillering, flower initiation and grain filling stages reduced the water potential and thereby also the osmotic potential. This was supported by Serraj and Sinclair (2002) who reported that solute accumulation in plant cell reduces the osmotic potential of the plants. Turgor pressure of wheat plant was reduced under drought at each growth stage. This decrease was attributed to decreased water potential of leaves under drought. Under deficit water condition relative water contents (RWC) of the leaf and leaf water potential also reduced, which had significant effect on photosynthesis (Siddique et al., 2000). Yadave et al. (2005) reported the reduction in total leaf area of the sorghum due to drought stress conditions. This reduction in leaf area induced by the drought stress can lead to reduce photosynthesis and thereby the crops yield (Kramer 1983). Erickson et al. (1991) reported that RWC of leaf signals the internal water balance of plant tissue leading to changes in tissue water content and thereby its dry weight. In our case, RWC were significantly reduced by creating water stress and more reduced RWC were recorded when crop faced deficit water at flower initiation stage. Water deficit lowered the leaf turgor, thus causing reduction in leaf expansion rate. This led to the reduced assimilatory surface of the crop which ultimately adversely affected yield and yield contributing factors. According to the earlier studies the adverse effect of drought stress on plant could be ameliorated by conserving water by increase in root penetration, partial closing of stomata and reduction in transpiration (Alfredo and Setter 2000., Hoad et al., 2001). Besides, it has been found that accumulation of $K$ (inorganic ion) can maintain the internal water balance, osmotic adjustment, turgor pressure and physiological processes (i.e. photosynthesis and stomatal opening) of plants which are subjected to water deficit (Serraj and Sinclair 2002).

Nutrients (N, P, K, Ca and $\mathrm{Na}$ ) uptake in the plant was considerably affected by the drought stress. Under drought stress the concentration of $\mathrm{N}, \mathrm{K}$ and $\mathrm{Na}$ increased. Highest $\mathrm{N}(27 \%)$ and $\mathrm{Na}(31 \%)$ contents were observed in plants where drought stress was imposed at grain filling stage, while highest $\mathrm{K}$ uptake (14\%) was observed with drought at flower initiation stage. The plants under water deficit have high $\mathrm{N}$ concentration which is because of the free amino acids accumulation that are not synthesized into protein (Alam 1994) since under drought stress nitrate reductase (enzyme responsible for assimilation of nitrate into amino acid) is adversely affected (Sinha and Nicholas 1981). 

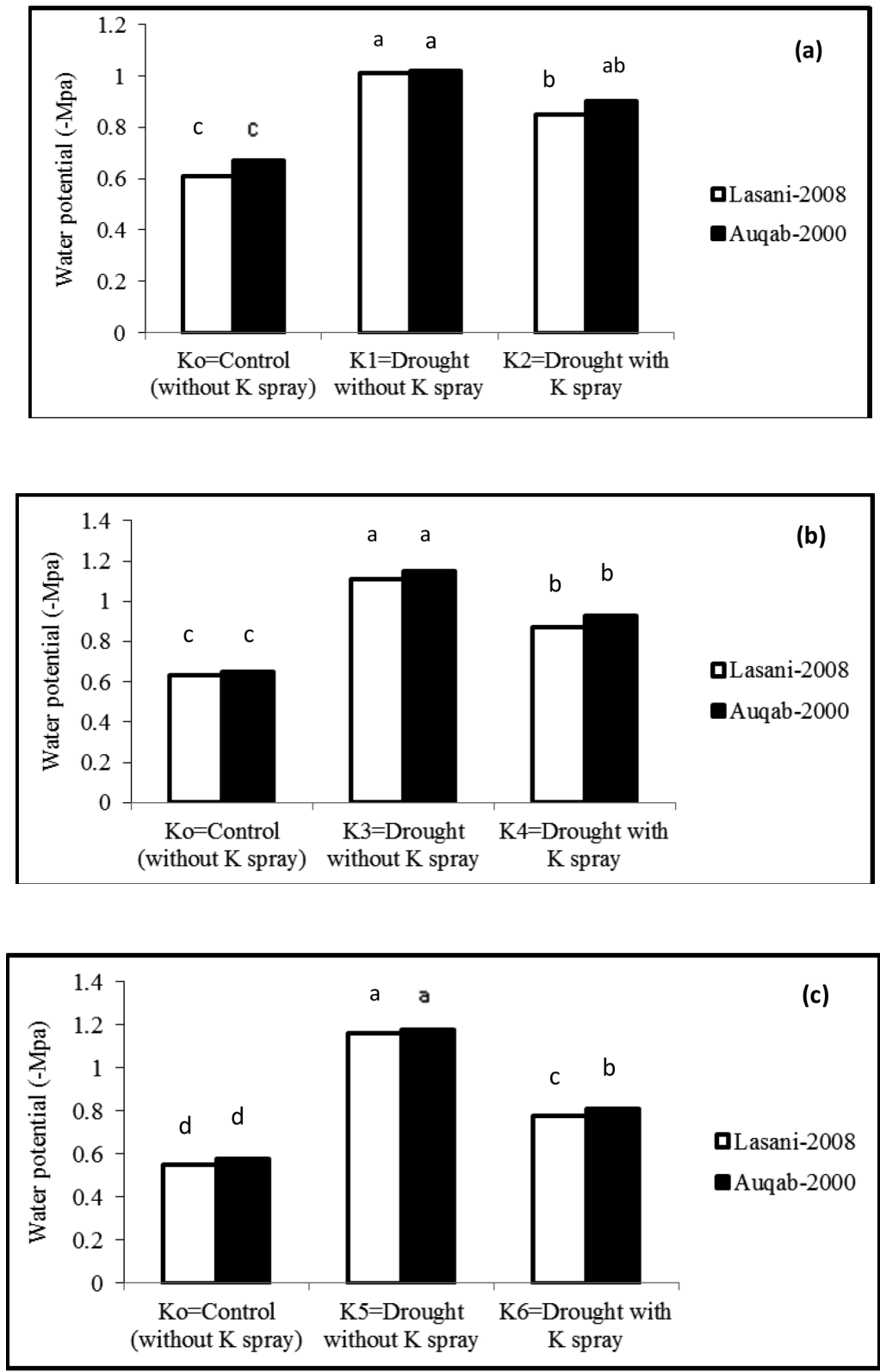

Figure 1. Effect of drought and potassium (K) spray at (a) tillering stage, (b) flower initiation stage and (c) grain filling stage of two wheat varieties on water potential (-Mpa). 

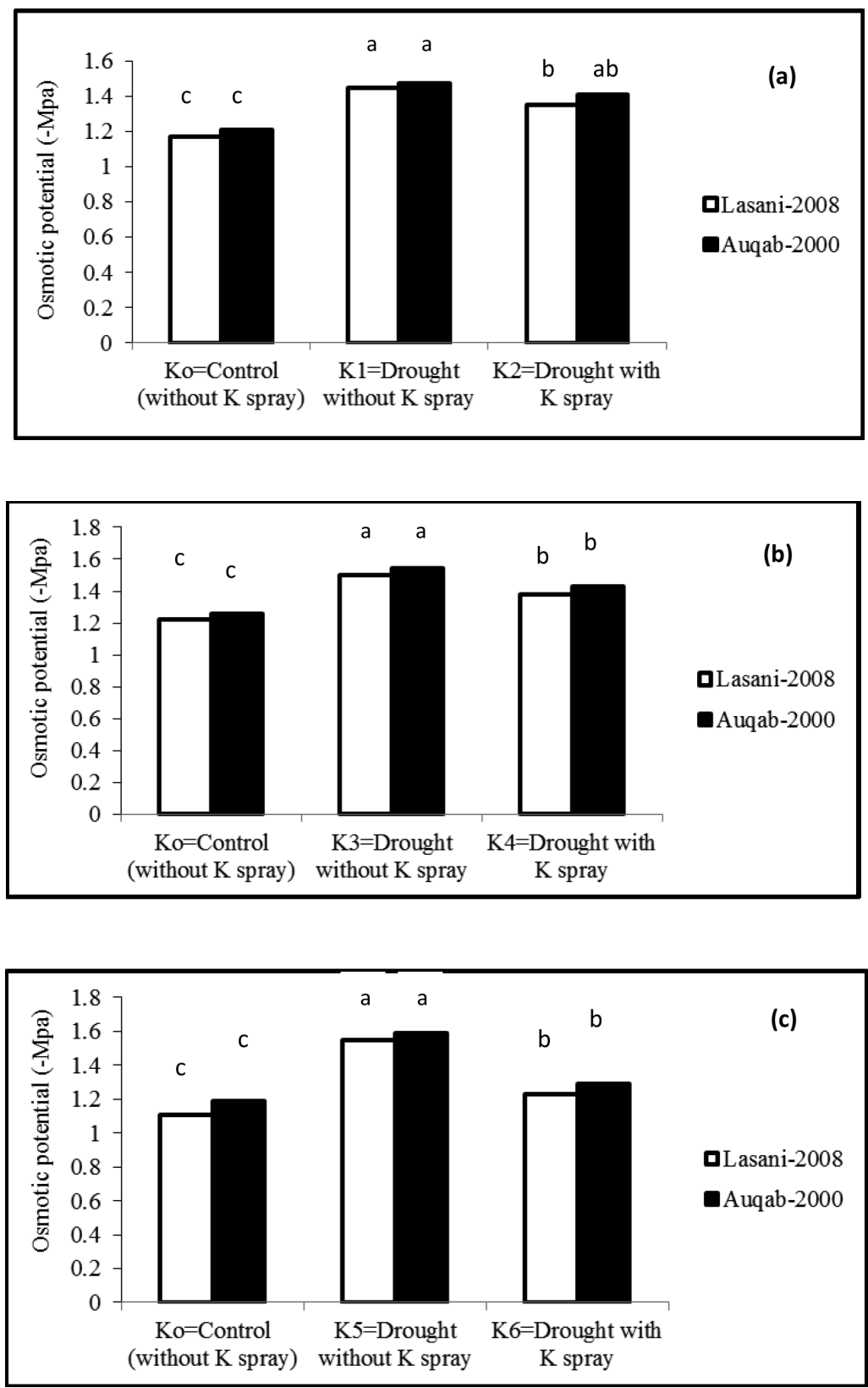

Figure 2. Effect of drought and potassium (K) spray at (a) tillering stage, (b) flower initiation stage and (c) grain filling stage of two wheat varieties on osmotic potential (-Mpa). 

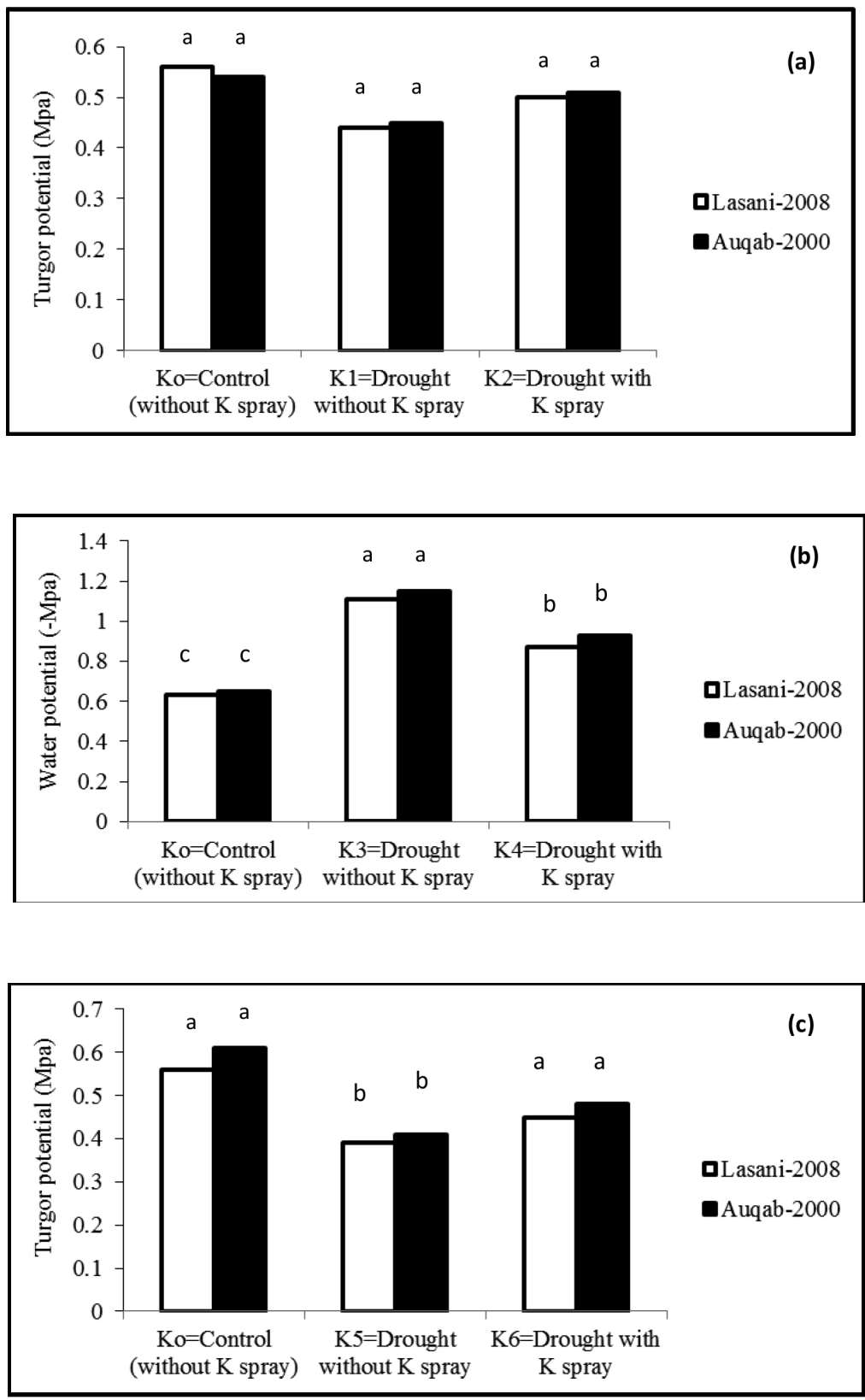

Figure 3. Effect of drought and potassium (K) spray at (a) tillering stage, (b) flower initiation stage and (c) grain filling stage of two wheat varieties on turgor potential (-Mpa). 
Thus the growth was inhibited under water deficit and plants particularly leaves accompanied by nitrate accumulation in plant tissue were affected (Sarwar et al., 1991). During K deficiency, ion is transported from older leaves to the younger leaves and then to meristematic regions due to high mobility of K (Wignarajah 1994), therefore plants may have accumulated $\mathrm{K}$ contents in developing ears for osmotic adjustment, so reduced $\mathrm{K}$ contents were observed in straw at maturity because awns contain chloroplasts and stomata and can photosynthesize (Arnon 1972). Increased $\mathrm{Na}$ concentration in plants (due to drought) may cause ion toxicity; with the application of $\mathrm{K}$ ion toxicity could be reduced because $\mathrm{K}$ is involved in osmotic regulation, maintenance of cell turgor pressure and can effectively compete with $\mathrm{Na}$ (Ashraf and Foolad 2005). Under increased drought stress K contents increased as reported by Ashraf et al. (1998) and Khondakar et al. (1983). Exogenous application of $\mathrm{K}$ reduced the adverse effect of drought by reducing the excessive uptake of $\mathrm{Na}$ by the plant under drought. Foliar applied $\mathrm{K}$ maintained the turgor pressure and internal water balance of the leaves. Exogenous spray of $\mathrm{K}$ on plants under drought at grain filling stage was most effective and it reduced the uptake of $\mathrm{Na}$ by $23 \%$ and increased the uptake of $\mathrm{N}$ and $\mathrm{K}$ by 10 and $24 \%$, respectively.

Water deficit has strong damaging effect on the plants and it reduced the uptake of $\mathrm{P}$ and $\mathrm{Ca}$ by plants. More reduced $\mathrm{P}$ and $\mathrm{Ca}$ (62 and 34\%, respectively) uptake was recorded in the plants where drought was created at flower initiation and at tillering stage, respectively. Water stress has the adverse effect on P uptake; P uptake decreased with decreasing soil moisture in wheat genotypes (Ashraf et al., 1998) and same response was reported by Turner (1985) in pepper. P deficiency appeared in low to moderate level of drought stress (Alam 1994). Kidambi et al. (1990) observed no effect of water stress on P uptake. On the other hand, higher P uptake in wheat plants was reported under water stress by Khondakar et al. (1983). Foliar application of K ameliorated the adverse effect of drought on plants and improved the uptake of $\mathrm{P}$ by $36 \%$ and $\mathrm{Ca}$ by $18 \%$ in plants under water deficit at grain filling stage.

\section{Conclusions}

The results of this study clearly demonstrated that water deficit at any critical crop growth stage severely affected the physiological and nutrients uptake parameters of wheat. Foliar application of $\mathrm{K}$ on a drought stressed plants at all growth stages improved the physiological performance and uptake of $\mathrm{N}, \mathrm{P}, \mathrm{K}$ and $\mathrm{Ca}$ but reduced Na uptake, grain filling stage being more responsive. All these findings lead us to recommend that for wheat crop under drought farmers should spray the crop with $1 \% \mathrm{~K}$ to minimize the negative effect of drought. This can have a dual benefit: by improving the physiological performance of wheat and supply of $\mathrm{K}$ nutrient to plants. For the foliar spray on a small scale, a common hand-boom sprayer can easily be used, whereas on large scale use of a mechanical boom-sprayer is advised.

\section{Acknowledgements}

The financial support of this study provided by Higher Education Commission of Pakistan is gratefully acknowledged. We are equally indebted to Nuclear Institute for Agriculture and Biology for providing technical support.

\section{References}

Alam, S.M. 1994. Nutrient by plants under stress conditions. In: Pessarakli M (eds) Handbook of Plant and Crop Stress, pp. 227-246. Marcel Dekker, New York.

Alfredo, A.C.A., Setter, T.L. 2000. Response of cassava to water deficit: Leaf area growth and abscisic acid. Crop. Sci. 40, 131-137. 
Arnon, I. 1972. Crop production in dry regions. In: Polunin N (eds) Leonard Hill Book Vol. 1, pp. 203-211. London.

Arora, A., Sairam, R.K., Srivastava, G.C. 2002. Oxidative stress and antioxidative systems in plants. Curr. Sci. 82, 1227-1238.

Ashraf, M., Foolad, M,R. 2005. Pre-sowing seed treatment-a shotgun approach to improve germination, plant growth, and crop yield under saline and non-saline conditions. Adv. Agron. 88, 223-271.

Ashraf, M., Yasmin, N. 1995. Responses of four arid zone grass species from varying habitat to drought stress. Biol. Plant. 37, 567-575.

Ashraf, M.Y., Ali, S.A., Bhatti, A.S. 1998. Nutritional imbalance in wheat genotypes grown at soil water stress. Acta Physiol. Plant 20, 307-310.

Blum, A. 2005. Drought resistance, water-use efficiency, and yield potential: Are they compatible, dissonant, or mutually exclusive? Aust. J. Agric. Res. 56, 1159-1168.

Cakmak, I. 2005. The role of potassium in alleviating detrimental effects of abiotic stresses in plants. J. Plant Nutr. Soil Sci. 168, 521-530.

Damon, P.M., Rengel, Z. 2007. Wheat genotypes differ in potassium efficiency under glasshouse and field conditions. Aust. J. Agric. Res. 58, 816-823.

Erickson, I.J., Ketring, D.L., Stone, J.F. 1991. Response of internal tissue water balance of peanut to soil water. Agron. J. 83, 248-253.

Farooq, M., Basra, S.M.A., Wahid, A., Cheema, Z.A., Cheema, M.A., Khaliq, A. 2008: Physiological role of exogenously applied glycinebetaine in improving drought tolerance of fine grain aromatic rice (Oryza sativa L.). J. Agron. Crop Sci. 194, 325-333.
Hoad, S.P., Russell, G., Lucas, M.E., Bingham, I.J. 2001. The management of wheat, barley and oats root systems. Adv. Agron. 74, 193-246.

Jenks, M.A., Hasegawa, P.M., Mohan, S.J. 2007. Advances in Molecular Breeding toward Drought and Salt Tolerant Crops, pp. 817 Springer, Dordrecht, The Netherlands.

Karamer, P.J. 1983. Plant water relations. Academic Press, New York, USA.

Khondakar, Z.H., Aslam, A., Rehman, S., Khan, T.H. 1983. Influence of soil moisture stress on yield, grain quality, availability and uptake of $\mathrm{N}, \mathrm{P}$ and $\mathrm{K}$ by wheat. Int. J. Tropical Agric. 1, 211-220.

Kidambi, S.P., Matches, A.G., Bolger, T.P. 1990. Mineral concentration in alfalfa and rainfoin as influenced by soil moisture level. Agron. J. 82, 229-236.

Lee, S.H., Ahsana, N., Lee, K.W., Kim, D.H., Lee, D.G., Kwak, S.S., Kwon, S.Y, Kim, T.H., Lee, B.H. 2007. Simultaneous overexpression of both $\mathrm{CuZn}$ superoxide dismutase and ascorbate peroxidase in transgenic tall fescue plants confers increased tolerance to a wide range of abiotic stresses. J. Plant Physiol. 164, 1626-1638.

Mengel, K., Kirkby, E.A. 2001. Principles of Plant Nutrition, 5th edn. pp. 864, Kluwer Academic Publishers Dordrecht, The Netherlands.

Nelson, D., Repetti, P., Adams, T., Creelman, R., Wu, J., Warner, D., Anstrom, D., Bensen, R., Castiglioni, P., Donnarummo, M. 2007. Plant nuclear factor Y (NF-Y) B subunits confer drought tolerance and lead to improved corn yields on water-limited acres. Proc Natl. Acad. Sci. USA, 104, 16450-16455.

Pennisi, E. 2008. The blue revolution, drop by drop, gene by gene. Science. 320, 171-173. 
Rivero, R.M., Kojima, M., Gepstein, A., Sakakibara, H., Mittler, R., Gepstein, S., Blumwald, E. 2007. Delayed leaf senescence induces extreme drought tolerance in a flowering plant. Proc. Natl. Acad. Sci. USA, 104, 19631-19636.

Sangakkara, U.R., Frehner, M., Nosberger, J. 2000. Effect of soil moisture and potassium fertilizer on shoot water potential, photosynthesis and partitioning of carbon in mungbean and cowpea. J. Agron. Crop Sci. 185, 201-207.

Sarwar, M., Ahmad, N., Nabi, G., Yasin, M. 1991. Effect of soil moisture stress on different wheat varieties. Pak. J. Agri. Res. 12, 275-280.

Serraj, R., Sinclair, T.R. 2002. Osmolyte accumulation: can it really help increase crop yield under drought conditions? Plant Cell Environ. 25, 333-341.

Siddique, M.R.B., Hamid, A., Islam, M.S. 2000. Drought stress effects on water relations of wheat. Bot. Bull. Acad. Sin. 41:35-39.

Sinha, S.K., Nicholas, D.J.D. 1981. Nitrate reductase. In: Paleg, L., Aspinall, D. (eds) The Physiology and Biochemistry of Drought Resistance in Plants, pp. 145-169. Academic Press, Sydney

Turner, N.C., Wright, G.C., Siddique, K.H.M. 2001. Adaptation of grain legumes (pulses) to water limited environments. Adv. Agron. 71, 123-231.
Wignarajah, K. 1995. Mineral nutrition of plants. In: Pessarakli, M. (eds) Handbook of plant and crop physiology, pp. 193-222. Marcel Dekker New York.

Wolf, B. 1982. A comprehensive system of leaf analysis and its use for diagnosing crop nutrient status. Comm. Soil Sci. Plant Anal. 13, 10351059 .

Yadav, S.K., Lakshmi, N.J., Maheswari, M., Vanaja, M., Venkateswarlu, B. 2005: Influence of water deficit at vegetative, anthesis and grain filling stages on water relation and grain yield in sorghum. Indian J. Plant Physiol. 10, 20-24.

Yang, X.H., Wen, X.G., Gong, H.M., Lu, Q.T., Yang, Z.P., Tang, Y.L., Liang, Z., Lu, C.M. 2007. Genetic engineering of the biosynthesis of glycinebetaine enhances thermotolerance of photosystem II in tobacco plants. Planta. 225, 719-733.

Zhu, J.M., Alvarez, S., Marsh, E.L., Noble, M.E., Cho, J.J., Sivaguru, M., Chen, S.X., Nguyen H.T., Wu, Y.J., Schachtman, D.P. 2007. Cell wall proteome in the maize primary root elongation zone. II. Region-specific changes in water soluble and lightly ionically bound proteins under water deficit. Plant Physiol. 145, 1533-1548. 